\title{
An Overview of New Insights into the Benefits of the Seagrass Posidonia oceanica for Human Health
}

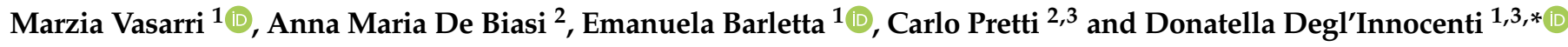 \\ 1 Department of Experimental and Clinical Biomedical Sciences, University of Florence, Viale Morgagni 50, \\ 50134 Florence, Italy; marzia.vasarri@unifi.it (M.V.); emanuela.barletta@unifi.it (E.B.) \\ 2 Interuniversity Center of Marine Biology and Applied Ecology "G. Bacci” (CIBM), Viale N. Sauro 4, \\ 57128 Livorno, Italy; debiasi@cibm.it (A.M.D.B.); pretti@cibm.it (C.P.) \\ 3 Department of Veterinary Sciences, University of Pisa, Viale delle Piagge 2, 56124 Pisa, Italy \\ * Correspondence: donatella.deglinnocenti@unifi.it
}

Citation: Vasarri, M.; De Biasi, A.M.; Barletta, E.; Pretti, C.; Degl'Innocenti, D. An Overview of New Insights into the Benefits of the Seagrass Posidonia oceanica for Human Health. Mar. Drugs 2021, 19, 476. https://doi.org/ $10.3390 /$ md19090476

Academic Editor:

Giuseppina Chianese

Received: 27 July 2021

Accepted: 23 August 2021

Published: 25 August 2021

Publisher's Note: MDPI stays neutral with regard to jurisdictional claims in published maps and institutional affiliations.

Copyright: (c) 2021 by the authors. Licensee MDPI, Basel, Switzerland. This article is an open access article distributed under the terms and conditions of the Creative Commons Attribution (CC BY) license (https:/ / creativecommons.org/licenses/by/ $4.0 /)$.

\begin{abstract}
Posidonia oceanica (L.) Delile is a Mediterranean-endemic angiosperm often described for its great ecological importance. Despite evidence of a millennia-old relationship between P. oceanica and humans, as well as traditional medicine applications, the potential benefits of P. oceanica for human health have been documented only recently. This review aims to compile newly acquired knowledge on $P$. oceanica bioactive properties that allow the scientific community to look at this plant as a promising source of natural therapeutical products for human health. Experimental investigations conducted in both in vitro cellular-based and in vivo animal models pave the way for new research projects aiming at the development of alternative and complementary therapeutic strategies based on $P$. oceanica against a wide range of pathological conditions.
\end{abstract}

Keywords: P. oceanica; angiosperm; marine natural products; seagrass; secondary metabolites; phytochemicals

\section{Introduction}

Seagrasses are flowering and rhizomatous plants that grow only in marine environments and form extensive underwater meadows. They are categorized into four families in the monocotyledonous order Alismatales: Cymodoceaceae, Hydrocharitaceae, Posidoniaceae, and Zosteraceae. They are among the most valuable coastal ecosystems on the planet in terms of the goods and services they provide [1,2].

Although often confused with algae, seagrasses are marine vascular plants deriving from higher terrestrial plants that have secondarily colonized marine habitats. Hence, they generally share most of their primary and secondary metabolism features with their relatives of the Alismatales order living in terrestrial and freshwater habitats [3].

Five species of seagrasses populate the Mediterranean Sea, Posidonia oceanica (L.) Delile, Cymodocea nodosa (Ucria), Zostera marina L., Zostera noltii Hornemann, and Halophila stipulacea (Forsskål) Ascherson (non-indigenous species) [4].

P. oceanica, a member of the Posidoniaceae family, is the most important species of seagrass for the Mediterranean Sea's ecological coastal balance due to its widespread distribution and abundance [5].

P. oceanica is a slow-growing marine phanerogam $\left(>10 \mathrm{~cm} \mathrm{year}^{-1}\right)$, organized in roots, rhizomes, and leaves [5,6].

Under favorable environmental conditions, $P$. oceanica colonizes vast underwater areas, forming extensive meadows from the surface to $40 \mathrm{~m}$ depth (although it has been recorded in particularly clear waters until $48 \mathrm{~m}$ depth), covering about $1.5 \%$ of the total Mediterranean Sea surface [7-9].

P. oceanica meadows are a highly complex and well-structured ecosystem known for their high biodiversity and great primary productivity, which is of paramount importance for the health of the Mediterranean coasts [10,11]. 
For this reason, in the last twenty years, $P$. oceanica has become one of the main targets of the protection and management of the Mediterranean marine environment. It has been included by the European Union's Habitat Directive (92/43/CEE) among the habitats of priority interest $[7,12,13]$ and it is protected under the Bern and the Barcelona Conventions, and other legislation at a national level. Moreover, the MFSD (2008/56/EC) selected $P$. oceanica as representative species of the angiosperm quality elements for the Mediterranean marine environment [14].

P. oceanica, in addition to its inestimable ecological value for the Mediterranean marine environment, has been used in the past for other purposes in the construction, industrial, and commercial sectors, as well as in the pharmacological field. Besides the knowledge handed down over time, in the last few years, a growing body of evidence have reinforced the awareness of the beneficial properties of $P$. oceanica phytocomplex for human health [15-20], thus enhancing the scientific community interest in P. oceanica as an unexplored resource of phytotherapeutic compounds.

This overview for the first time focuses on recent advances in determinations of $P$. oceanica biological activities, in particular its potential health benefits.

\section{Ecological Significance of P. oceanica Seagrass Ecosystem}

In the Mediterranean Sea, the dominant endemic seagrass P. oceanica forms widespread ecosystems with high levels of biodiversity and productivity [7,21,22]. Figure 1 summarized a variety of ecologically and geologically important functions of P. oceanica [23-25].

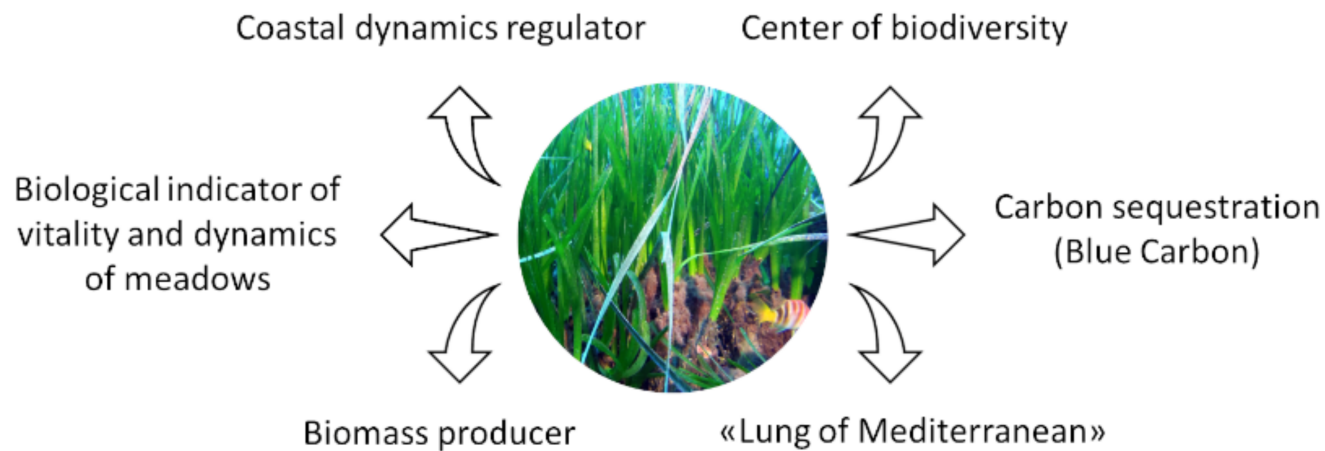

Figure 1. Summary list of the ecological significance of P. oceanica seagrass.

P. oceanica is considered of paramount importance being a hot spot of biodiversity, hosting about $20-25 \%$ of all species living in the Mediterranean Sea. Leaves and rhizomes offer substrata suitable for settlement and growth of a number of sessile organisms that form stratified assemblage guaranteeing the development of microniches for different taxonomic groups. About one-hectare meadows can host up to 350 different species of animals, residents, or migrants, thus offering shelter and nourishment to cephalopods, bivalves, gastropods, echinoderms, tunicates, and fish, also of considerable economic importance. The rich and diversified animal and plant community populating these grasslands contributes to create a complex trophic network, highly efficient and productive, capable of exporting energy to other systems $[7,26]$. Other studies have pointed out that the leaves of P. oceanica are a rich source of biochemical components, major and essential trace elements, making the seagrass of great nutritional value to marine organisms and an essential role in the marine food chain [27].

P. oceanica seagrass produces a large amount of plant biomass, ranging between 400 and $2500 \mathrm{gDW} / \mathrm{m}^{2} / \mathrm{y}^{-1}$, with decreasing values as depth increases. The contribution of the autotrophic epiphytes commonly associated with this plant raises these values dramatically to $2000-3000 \mathrm{gDW} / \mathrm{m}^{2} / \mathrm{y}^{-1}$. Because of these characteristics, $P$. oceanica meadows are regarded as one of the most productive of the Earth's ecosystems $[7,26]$. 
P. oceanica is known as "the lung of the Mediterranean" because it can emit up to $20 \mathrm{~L}$ of oxygen per day per square meter of meadows, making it the most important source of oxygen supplied by coastal waters [24,28].

P. oceanica ecosystem is also important in coastal dynamics, as it contrasts gradual silting, stabilizes sediment, protects the coastline from erosion through seabed consolidation, and attenuates swells and waves through the oscillatory movement of its leaves [29,30].

The floating dead leaves of P. oceanica (massive in autumn) that reach the coast create dense deposits along with other debris and deposits; when conditions allow, they can consolidate and produce a very compact and strong structure called "banquettes", which are essential for protecting the coast from erosion [7,31,32].

Coastal areas are often characterized by environmental disturbances both due to natural events and anthropological activities (overexploitation, physical modification, nutrient and sediment pollution, introduction of non-native species, climate change), with consequent impacts on the marine ecosystem [33].

Seagrass meadows are subjected to all the mentioned threats so that they are presently experiencing a decline globally [34] and are among the most threatened ecosystems on earth [35]. This is especially true for the Mediterranean, a semi-enclosed basin under severe demographic, urban, and industrial pressures, and where climate change is having a significant impact [36]. Global acidification has been clearly demonstrated to be a new and concerning threat to the health of marine and terrestrial ecosystems. As a result, several studies have been conducted to investigate the role of coastal vegetation in carbon sequestration (Blue Carbon). P. oceanica has the most organic carbon stores that have been documented [37] and can be considered an "outlier" within seagrass species. Under this contest, the loss of $P$. oceanica meadows assumes greater importance.

Its regression may result in the erosion and rapid remineralization of the carbon-rich soils stored beneath the canopy, in particular in exposed locations, thus releasing $\mathrm{CO}_{2}$. Furthermore, in areas where P. oceanica dies and the leaf canopy disappears, the underlying matte is no longer protected against erosion; dismantling of the matte will amplify the remineralization process accelerating climate change effects in a similar way to fossil fuels.

For this reason, P. oceanica has long been used as an excellent biological indicator of the vitality and dynamics of meadows and human influence on the marine environment $[24,25,38,39]$.

Hence, P. oceanica is an essential resource for humans, but at the same time, it represents a fragile ecosystem with recovery times in hundreds of years. Faced with the dramatic threat of $P$. oceanica meadows regression, in the last few years, numerous environmental projects have been carried out for transplanting and reforesting the seagrass in the seabed to support the conservation of P. oceanica as one of the most precious and important habitats for marine environment and humans.

In this context, a recent study has developed an efficient system for the regeneration of P. oceanica seagrass by storing free cells at low temperatures and initiating cell encapsulation. Cell encapsulation was the only successful method to acclimatize cells to salinity, preserve artificial material for sowing, and obtain embryos. This system could help solve problems related to the intractable nature of in vitro regeneration of marine phanerogams [40].

\section{Historical and Traditional Medical Uses of P. oceanica}

Even before discovering its enormous ecological value, archaeological and historical evidence tells of a relationship lasting for millennia between humans and P. oceanica seagrass.

Curiously, in the cave of Lazaret, in the French Maritime Alps, remains of leaves were found dating back to the end of the Riss glaciation (over 100 thousand years ago), presumably used as a bed by the occupants [41].

P. oceanica claims numerous traditional uses in human history in various commercial and industrial sectors thanks to its innumerable properties (Figure 2). The first details on P. oceanica use in human civilization date back to ancient Egypt, where the P. oceanica egagropils (agglomerates of fairly spherical fibers from dead leaves of $P$. oceanica formed 
by hydrodynamics in shallow waters and then rejected on the beaches) were used for the production of footwear $[42,43]$.

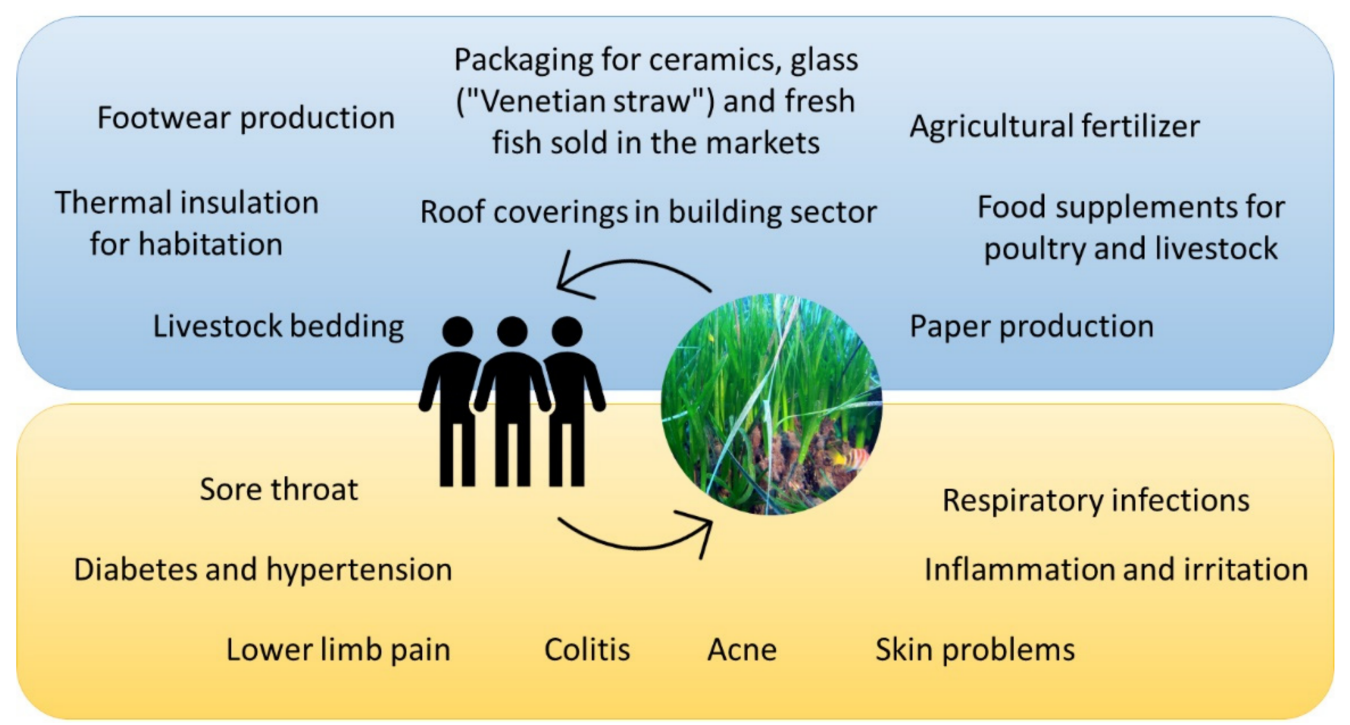

Figure 2. Schematic list of traditional roles of P. oceanica seagrass in both the commercial, industrial, and agricultural sectors (blue box) and in the medical field for the treatment of human health disorders (yellow box).

Moreover, for centuries P. oceanica leaves were used by the Venetians to wrap and transport their famous delicate glass, these leaves were in fact known as "Venetian straw" [44]. They were also used as packaging for ceramics and even for fresh fish sold in the markets. Furthermore, at the beginning of the twentieth century, the coastal populations of northern Africa (Egypt, Libya, Tunisia) exploited the biological characteristics of P. oceanica also in the building sector by using dry leaves as roof coverings [45] and thermal insulation for habitation [44]. P. oceanica also claims use in the agricultural field. Traditionally, P. oceanica leaves were used as agricultural fertilizer to improve the characteristics of the soil, a use which went for a long time by the farmer of the Mediterranean coast $[46,47]$. However, in 2009, the biochemical and mineral content of P. oceanica was more thoroughly studied. The $P$. oceanica mineral content, especially calcium (Ca, $3890.00 \mathrm{mg} / 100 \mathrm{~g})$, phosphorus $(\mathrm{P}, 930.00 \mathrm{mg} / 100 \mathrm{~g})$, and sodium $(\mathrm{Na}, 2765.00 \mathrm{mg} / 100 \mathrm{~g})$, was found to be significantly higher than the allowable concentrations proposed in Compost Management Program (2012) (Ca: 3000, P: 250 and Na: $1000 \mathrm{mg} / 100 \mathrm{~g}$ ) [27,48], thus revising the traditional use of P. oceanica as an organic fertilizer and/or compost.

In Tunisia, P. oceanica leaves were used as livestock bedding, still in use today thanks to their antifungal and insect repellent properties. Considering the nutritional value of P. oceanica leaves similar to that of fodder plants, they were also used as food supplements for poultry and livestock [7]. Among other uses, P. oceanica was employed in the production of paper in the late nineteenth century $[49,50]$.

The material extracted from $P$. oceanica has also been used experimentally for other industrial applications, such as for methane and nitrocellulose production [51]. Beyond varied applications in human activities, P. oceanica seagrass has traditionally been used also as a medical plant in the treatment of various human disorders (Figure 2). The first information on the P. oceanica healing properties comes from ancient Egypt, where it was supposedly used for sore throat and skin problems [52]. An old botany handbook of Cazzuola also mentions P. oceanica as a popular pharmacopeia product [53]. It has also been documented that $P$. oceanica leaves were used to treat inflammation and irritation, but also as a remedy for acne, lower limb pain, and colitis [54]. On the other hand, the curious use of P. oceanica as padding for cushions and mattresses dates back to the sixteenth century. It is believed that this practice served to prevent respiratory infections and alleviate the 
conditions of people with tuberculosis. The use of $P$. oceanica leaves decoction as a natural remedy for diabetes and hypertension by the inhabitants of the coastal areas of Western Anatolia belongs to a more recent tradition [55].

Queen of the seas for 120 million years, P. oceanica has therefore proved to be a precious ally for the care of human health.

\section{Phytochemical Compounds of P. oceanica Leaves}

Numerous characterization studies have shown that P. oceanica is a rich source of secondary metabolites (Table 1), mainly represented by phenolic compounds [56], essential in plant self-protection from photosynthetic stress, reactive oxygen, anthropogenic pressures, predators, and pathogens $[57,58]$.

Chicoric acid is reported as the major constituent of $P$. oceanica leaves $[15,59,60]$. However, P. oceanica leaves also abound with caftaric, gentisic, chlorogenic, caffeic, ferulic, cinnamic, gallic, and $p$-coumaric acids [15,19,56,59,61]. In addition, quercetin, myricetin, kaempferol, and isorhamnetin are found in the diethyl layer of a hydrochloric acid solution used for extraction from $P$. oceanica leaves, were the most represented secondary metabolites belonging to the class of flavonoids $[62,63]$.

Other phenolic derivatives were identified and quantified in P. oceanica leaves extracts, including phloroglucinol, pyrocatechol, pyrogallol, vanillin aldehyde, 4-hydroxybenzaldehyde, 3,4-dihydroxybenzaldehyde, benzoic acid, $p$-hydroxybenzoic acid, $p$-anisic acid, vanillic acid, syringic acid, proanthocyanidins, and calchones (as phloretin and phloridzin) [56,59,62,63].

The presence of long-chain fatty acids in P. oceanica seagrass is another distinguishing feature. The lipid fraction of $P$. oceanica leaves extracts was discovered to be primarily composed of palmitic, palmitoleic, oleic, and linoleic acids, as well as the phytosteroids campesterol, stigmasterol, and $\beta$-sitosterol [64]. Polyphenol-derived lignin was discovered to be present in all plant tissues [65].

Table 1. Structures and molecular formulas of major compounds isolated from P. oceanica leaves.

\begin{tabular}{|c|c|c|c|}
\hline Compound & Molecular Formula & Structure & References \\
\hline Chicoric Acid & $\mathrm{C}_{22} \mathrm{H}_{18} \mathrm{O}_{12}$ & & {$[15,59-61]$} \\
\hline Caftaric Acid & $\mathrm{C}_{13} \mathrm{H}_{12} \mathrm{O}_{9}$ & & {$[15,19,56,59,61]$} \\
\hline Gentisic Acid & $\mathrm{C}_{7} \mathrm{H}_{6} \mathrm{O}_{4}$ & & {$[15,19,56,59,61]$} \\
\hline Chlorogenic Acid & $\mathrm{C}_{16} \mathrm{H}_{18} \mathrm{O}_{9}$ & & {$[15,19,56,59,61]$} \\
\hline Caffeic Acid & $\mathrm{C}_{9} \mathrm{H}_{8} \mathrm{O}_{4}$ & & {$[15,19,56,59,61]$} \\
\hline Ferulic Acid & $\mathrm{C}_{10} \mathrm{H}_{10} \mathrm{O}_{4}$ & & {$[15,19,56,59,61]$} \\
\hline
\end{tabular}


Table 1. Cont.

\begin{tabular}{|c|c|c|c|}
\hline Compound & Molecular Formula & Structure & References \\
\hline Cinnamic Acid & $\mathrm{C}_{9} \mathrm{H}_{8} \mathrm{O}_{2}$ & & {$[15,19,56,59,61]$} \\
\hline Gallic Acid & $\mathrm{C}_{7} \mathrm{H}_{6} \mathrm{O}_{5}$ & & {$[15,19,56,59,61]$} \\
\hline$p$-Coumaric Acid & $\mathrm{C}_{9} \mathrm{H}_{8} \mathrm{O}_{3}$ & & {$[15,19,56,59,61]$} \\
\hline Quercitin & $\mathrm{C}_{15} \mathrm{H}_{10} \mathrm{O}_{7}$ & & {$[62,63]$} \\
\hline Myricetin & $\mathrm{C}_{15} \mathrm{H}_{10} \mathrm{O}_{8}$ & & {$[62,63]$} \\
\hline Kaempferol & $\mathrm{C}_{15} \mathrm{H}_{10} \mathrm{O}_{6}$ & & {$[62,63]$} \\
\hline Isorhamnetin & $\mathrm{C}_{16} \mathrm{H}_{12} \mathrm{O}_{7}$ & & {$[62,63]$} \\
\hline Phloroglucinol & $\mathrm{C}_{6} \mathrm{H}_{6} \mathrm{O}_{3}$ & & {$[56,59,62,63]$} \\
\hline Pyrocatechol & $\mathrm{C}_{6} \mathrm{H}_{6} \mathrm{O}_{2}$ & & {$[56,59,62,63]$} \\
\hline Pyrogallol & $\mathrm{C}_{6} \mathrm{H}_{3}(\mathrm{OH})_{3}$ & & {$[56,59,62,63]$} \\
\hline Vanillin & $\mathrm{C}_{8} \mathrm{H}_{8} \mathrm{O}_{3}$ & & {$[56,59,62,63]$} \\
\hline 4-Hydroxybenzaldehyde & $\mathrm{C}_{7} \mathrm{H}_{6} \mathrm{O}_{2}$ & & {$[56,59,62,63]$} \\
\hline 3,4-Dihydroxybenzaldehyde & $\mathrm{C}_{7} \mathrm{H}_{6} \mathrm{O}_{3}$ & & {$[56,59,62,63]$} \\
\hline Benzoic acid & $\mathrm{C}_{6} \mathrm{H}_{5} \mathrm{COOH}$ & & {$[56,59,62,63]$} \\
\hline 4-Hydroxybenzoic acid & $\mathrm{C}_{7} \mathrm{H}_{6} \mathrm{O}_{3}$ & & {$[56,59,62,63]$} \\
\hline$p$-Anisic acid & $\mathrm{C}_{8} \mathrm{H}_{8} \mathrm{O}_{3}$ & & {$[56,59,62,63]$} \\
\hline Vanillic acid & $\mathrm{C}_{8} \mathrm{H}_{8} \mathrm{O}_{4}$ & & {$[56,59,62,63]$} \\
\hline Syringic acid & $\mathrm{C}_{9} \mathrm{H}_{10} \mathrm{O}_{5}$ & & {$[56,59,62,63]$} \\
\hline
\end{tabular}


Table 1. Cont.

\begin{tabular}{|c|c|c|c|}
\hline Compound & Molecular Formula & Structure & References \\
\hline Phloretin & $\mathrm{C}_{15} \mathrm{H}_{14} \mathrm{O}_{5}$ & & {$[56,59,62,63]$} \\
\hline Phlorizin & $\mathrm{C}_{21} \mathrm{H}_{24} \mathrm{O}_{10}$ & & {$[56,59,62,63]$} \\
\hline Palmitic acid & $\mathrm{C}_{16} \mathrm{H}_{32} \mathrm{O}_{2}$ & & [64] \\
\hline Palmitoleic acid & $\mathrm{C}_{16} \mathrm{H}_{30} \mathrm{O}_{2}$ & & [64] \\
\hline Oleic acid & $\mathrm{C}_{18} \mathrm{H}_{34} \mathrm{O}_{2}$ & & [64] \\
\hline Linoleic acid & $\mathrm{C}_{18} \mathrm{H}_{32} \mathrm{O}_{2}$ & & {$[64]$} \\
\hline Campesterol & $\mathrm{C}_{28} \mathrm{H}_{48} \mathrm{O}$ & & {$[64]$} \\
\hline Stigmasterol & $\mathrm{C}_{29} \mathrm{H}_{48} \mathrm{O}$ & & {$[64]$} \\
\hline$\beta$-Sitosterol & $\mathrm{C}_{29} \mathrm{H}_{50} \mathrm{O}$ & & [64] \\
\hline Posidozinol & $\mathrm{C}_{16} \mathrm{H}_{32}$ & & [66] \\
\hline
\end{tabular}

In 2013, posidozinol, new sesquiterpene alcohol, was isolated from a chloroform extract of P. oceanica leaves [66].

Scientific research in recent years has shed light on the ability of the P. oceanica secondary metabolites to exert biological properties effectively due to the synergistic action of its phytochemical components. The most recent developments in the field of herbal medicine on the health-promoting properties and benefits that $P$. oceanica could provide are listed and summarized below

\section{P. oceanica Bioactive Properties: From Tradition to New Horizons}

\subsection{Antibacterial, Antifungal, and Antiviral Role}

As early as 1989, Bernard and Pesando attributed to an extract of $P$. oceanica rhizomes for the Mediterranean maritime flora anti-bacteria and anti-fungal properties [67]. Subsequent studies showed that extracts from $P$. oceanica leaves also had antibacterial activities against both Gram-positives and Gram-negatives, with particular efficacy against $P$. aeruginosa and S. aureus [68]. P. oceanica has also shown antiviral capabilities, notably, in 2018 Farid et al. obtained that P. oceanica ball extracts inhibited H5N1 virus infection by 45\% [69]. 
In recent years, scientific research has shown increasing interest in identifying natural compounds with antioxidant and antimicrobial activity with potential applications in food science [70]. The current trend in food processing is focusing on the use of natural compounds, which are considered safe alternatives to chemical additives [71,72]. The exploration of new phytocompounds with these functional properties is a topic of great current interest with human well-being as the main goal. In fact, some microorganisms can have a negative impact on food quality, safety, and shelf life, and oxidative processes can have an impact on food quality, affecting human health.

$P$. oceanica seagrass, as an antimicrobial and antioxidant agent, has piqued the scientific community's interest in its potential applications in food science. A number of studies have looked into the potential applications of P. oceanica in the field of food preservation by reducing and eliminating pathogens and spoilage microorganisms in food $[73,74]$.

In 2017, a P. oceanica leaves extract was found to reduce microbial spoilage in fresh peaches, particularly that caused by the Pseudomonas population, and so proposed for use on fresh-cut fruit [73]. This discovery could pave the way for the use of novel natural extracts on ready-to-eat vegetables, increasing the consumer appeal of these healthy foods.

The growing interest in P. oceanica extracts in the field of food science has prompted researchers to develop more environmentally friendly alternative methods that avoid the use of toxic solvents to optimize the processes of extracting phytochemical compounds from P. oceanica leaves. Indeed, the use of a water-soluble extraction method has been shown to more ecologically ensure the maintenance of $P$. oceanica biological properties, including antioxidant, antifungal activities, especially against food-borne fungi-i.e., P. digitatum, P. italicum, P. expansum, B. cinerea, G. candidum, and A. niger-and antiviral against feline calicivirus and murine norovirus. Future investigations aim to maximize extraction yields and antioxidant, antifungal, and antiviral properties of the extracts [74].

\subsection{Insights into the Bioactivities of P. oceanica with Potential Human Health Applications}

Comprehending the potential of the natural world to produce secondary metabolites is remarkable in a wide range of fields, including drug discovery. With more than $70 \%$ of the Earth's surface, the marine environment is the largest terrestrial habitat and prolific supplier of biologically active compounds because of its extraordinary biodiversity, which is relatively unexplored compared to terrestrial environments.

The variety of bioactive marine compounds with great pharmaceutical potential is unique, and their production is aided by the chemical and physical conditions of the sea. Marine natural products with a wide range of biological activities have increasingly attracted the attention of many researchers as a useful resource for developing drugs for the management of human health [75].

Beyond its invaluable ecological and environmental significance, scientific research in recent years has fueled interest in the hitherto unexplored phytochemical properties of P. oceanica for potential pharmaceutical applications in human health.

Recent studies have shown that $P$. oceanica acts through a variety of mechanisms of action, establishes molecular interactions, and triggers multiple signaling pathways. These insights are schematized in Figure 3 and described in detail below.

The high content of phenolic compounds and their derivatives make P. oceanica leaves a rich source of antioxidant molecules. Physiologically, P. oceanica exploits its ability to stimulate the functionality of antioxidant enzymes as a defense mechanism against various environmental pressures [76], including increasingly frequent and strong thermal stress in the face of human-induced climate change [77] or stressful conditions such as competition from invasive macroalgae $[76,78]$, which strongly contribute to the phenomenon of seagrass regression in the Mediterranean.

In scientific research, many natural products with antioxidant properties have found applications in a wide range of fields, including biomedicine. The exploration of new natural products with these functional properties is a topic of great current interest for human well-being as the main focus. 


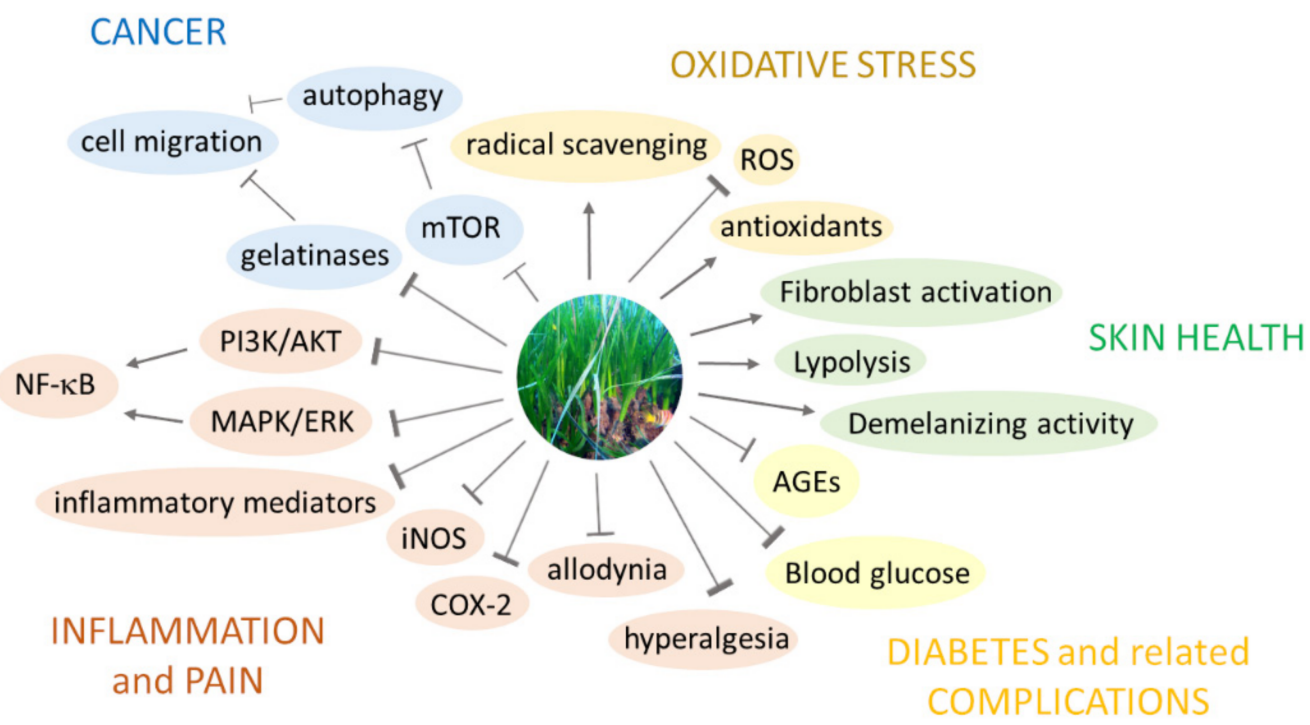

Figure 3. Scheme of the different modes of action of P. oceanica and possible therapeutic targets for human health.

P. oceanica seagrass may find application in the prevention of cellular damage and oxidative stress-related diseases, due to its antioxidant power. $P$. oceanica leaves extract, rich in chicoric acid, was shown to have effects on human dermal fibroblast proliferation and collagen production, as well as anti-melanogenic properties in the human melanoma cell line MeWo and lipolytic properties in human subcutaneous preadipocytes; these properties were attributable to its antioxidant power [15]. Therefore, the antioxidant activity of P. oceanica extract may be associated with protection against wrinkle formation, skin aging, unwanted hyperpigmentation, and cellulite, in which oxidative stress plays a crucial role.

The imbalance between the production of reactive oxygen species (ROS) and their elimination by protective mechanisms often underlies oxidative damage and thus the onset and progression of inflammatory diseases [79]. Under conditions of inflammation, the uncontrolled production of ROS during the so-called "oxidative burst" is closely related to the histolesivity of inflammation, which represents the "dark" side of the inflammatory process associated with suffering cells and tissues. A P. oceanica leaves extract was shown to decisively suppress the expression level of key inflammation-associated enzymes, namely inducible nitric oxide synthase (iNOS) and cyclooxygenase-2 (COX-2), impairing the production of cell- and tissue-damaging metabolites, like nitric oxide (NO) as a precursor of peroxynitrite, and generally the production of intracellular ROS in lipopolysaccharide (LPS)-stimulated murine macrophages RAW264.7 [17]. The transcription factor nuclear factor- $\mathrm{B}(\mathrm{NF}-\mathrm{KB})$ regulates genes involved in inflammation and tumorigenesis [80]. One possible mechanism by which $P$. oceanica exerts its anti-inflammatory activity is the inhibition of NF-KB activity. Vasarri et al. (2019) found that P. oceanica inhibited LPS-induced $\mathrm{NF}-\mathrm{KB}$ activation by preventing phosphorylation and nuclear translocation of the p65 subunit of NF-KB [17].

In the NF- $\mathrm{KB}$ signaling pathway, IKB is an inhibitory protein that binds to inactive cytosolic NF- $\kappa B$. Following a pro-inflammatory stimulus, I $\kappa B$ kinase (IKK) phosphorylates $\mathrm{I} \kappa \mathrm{B}$, degrading it and allowing $\mathrm{NF}-\mathrm{\kappa B}$ to translocate into the nucleus. P. oceanica has been shown to prevent nuclear translocation of NF- $\mathrm{KB}$ by restoring basal levels of IкB. The anti-inflammatory activity afforded by P. oceanica also occurred by modulating signaling pathways upstream of NF-KB pathway, i.e., mitogen-activated protein kinase (MAPK)/extracellular signal-regulated kinase (ERK) and phosphatidylinositol 3-kinase (PI3K)/protein kinase B (AKT). Notably, P. oceanica inhibited LPS-induced activation of ERK and AKT [17].

A further in vivo study on different models of acute inflammatory pain in CD-1 mice provides pharmacological evidence for the anti-inflammatory and analgesic role of a 
P. oceanica leaves extract. Acute oral administration of the extract has been shown to dosedependently inhibit both inflammation-induced hypersensitivity after intraplantar injection of carrageenan and inflammatory pain induced by intraplantar injection of interleukin$1 \beta$ (IL-1 $\beta$ ) or formalin or against the physiological pain threshold in naive animals [81]. $P$. oceanica also reduced tissue myeloperoxidase (MPO) activity and tissue concentrations of inflammatory cytokines, such as tumor necrosis factor- $\alpha$ (TNF- $\alpha)$ and IL-1 $\beta$ [81].

Other in vitro bioactivity studies have described the ability of a P. oceanica leaves extract to inhibit the migration and invasiveness of tumor cells, such as human fibrosarcoma HT1080 cells [19] and human neuroblastoma cells SHSY5Y [18]. This role has been related to its ability to inhibit the expression and activity of metalloproteases 2 and 9 proteolytic enzymes playing a key role in the processes of tumor metastasis by degrading the extracellular matrix [19]. The molecular mechanisms associated with the anti-migratory effects in cancer cells involve the activation of autophagy [16], a conserved evolutionary process that mediates the degradation of cytoplasmic material [82].

Leri et al. (2018) suggested that the activation of autophagy afforded by P. oceanica is due to the concomitant and reverse modulation of ERK and AKT signaling pathways culminating in the inhibition of the mammalian target of rapamycin (mTOR), the master regulator of autophagy [16]. The interaction between $P$. oceanica and the ERK and AKT pathways provides possible explanations for many of the beneficial effects of $P$. oceanica.

Typically, the mode of action of anticancer drugs is based primarily on differential toxicity and sensitivity of actively growing tumor cells compared with normal cells. The reported ability of the $P$. oceanica phytocomplex to act against cell migration by a completely nontoxic mechanism makes it a promising reservoir of potent and safe molecules that can defend against neoplasms, but also against other chronic pathophysiological processes, such as neurodegeneration, inflammation, and skin aging, in whose progression gelatinolytic activity is the hallmark [16,19].

Many natural products have demonstrated effective anticancer activities for many years, resulting in valuable chemotherapeutic and cancer prevention agents [83]. However, the reduced bioavailability of natural products, which is often due to their hydrophilic or lipophilic nature, limits their use in anticancer therapy as well as the treatment of other diseases [84].

Different nanosystems (e.g., liposomes, polymer nanocapsules, and dendrimers) are designed to deliver drugs and are composed of materials that can mask the unfavorable biopharmaceutical properties of the encapsulated molecule [84]. The use of these nanodelivery systems can increase the in vivo stability and bioavailability of the delivered natural products, but also improve their selective activity against cancer cells. In this context, P. oceanica leaves extract has been found suitable for the use of nanotechnology. Piazzini et al. (2019) demonstrated that the use of polymeric nanomicelles of Soluplus ${ }^{\circledR}$, a tri-block copolymer consisting of polyvinylcaprolactam-polyvinylacetate-polyethylene glycol, to deliver the extract allowed both to increase the aqueous solubility of $P$. oceanica phytocomplex and to improve its bioactivity in terms of inhibition of human neuroblastoma SHSY5Y cell migration. The prolonged release of the extract from the nanomicelles could be the factor responsible for the demonstrated biological enhancement of P. oceanica [18]. The development of an appropriate delivery nanosystem of $P$. oceanica may offer an advanced approach to improve the bioavailability and/or optimize the solubility and stability of P. oceanica extract promoting its potential health benefits.

Treatment with medicinal plants is as old as mankind. Knowledge of the use of medicinal plants is the result of many years of fighting disease, during which humans learned to look for medicine in nature. Modern science has recognized the active action of medicinal plants and has included a number of drugs of plant origin known to ancient civilizations and used over millennia [85]. The use of $P$. oceanica seaweed as a medicinal plant dates back to Mediterranean civilizations, which used it to treat a variety of human health problems, as described above. P. oceanica leaves decoction was used as a natural remedy for diabetes and hypertension by the people of western Anatolia [55]. In this 
regard, Gokce et al. (2008) demonstrated that oral administration of an extract of P. oceanica in alloxan-induced diabetic rats strongly restored the activity of antioxidant enzymes and decreased the process of lipid peroxidation, as well as reduced blood glucose [55]. The ramification between the antioxidant, vasoprotective, and hypoglycemic properties of $P$. oceanica extract could provide therapeutic benefits in diabetes-related endothelial dysfunction and oxidative damage.

Persistent hyperglycemia or uncontrolled diabetes has the potential to cause severe complications; an unavoidable consequence of a long-lasting hyperglycemic state is increased accumulation of advanced glycation end products (AGEs), a heterogeneous group of products obtained from the nonenzymatic Maillard reaction between circulating macromolecules and free-reducing sugars. P. oceanica leaves extract has been shown to inhibit the formation of AGEs in vitro [20]. The dual antidiabetic and anti-glycation role of P. oceanica may help manage diabetes and prevent associated complications.

Overall, P. oceanica phytocomplex is indicated to the entire scientific community as a reservoir of molecules potentially exploitable in various applications in human health (Figure 4).

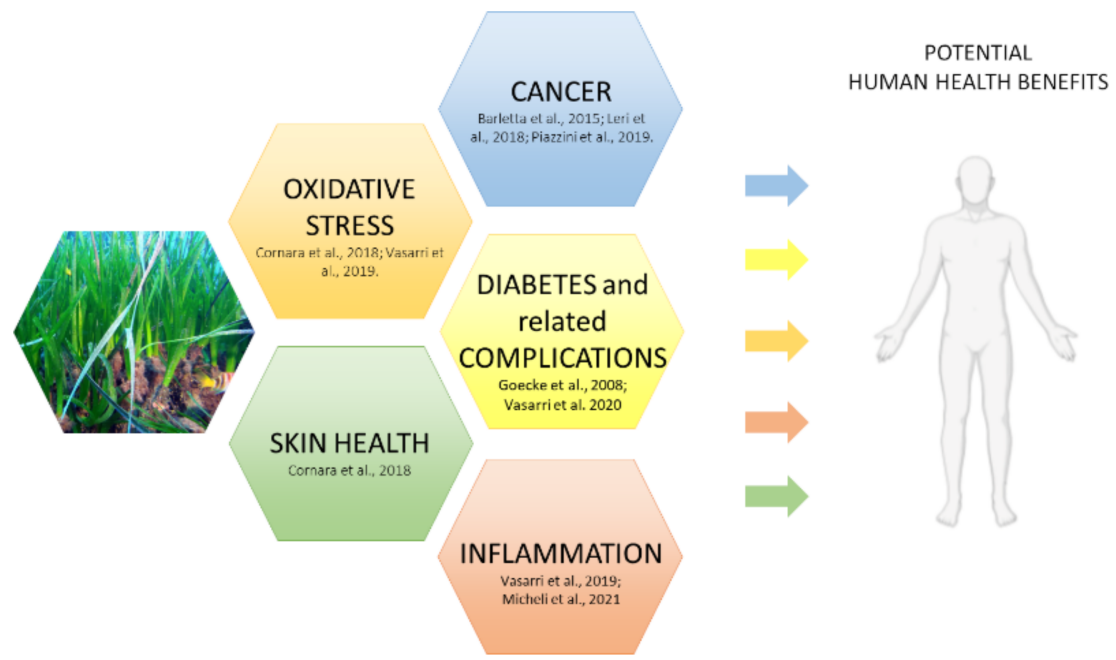

Figure 4. Schematic representation of the potential benefits of $P$. oceanica phytocomplex in human health.

\section{Conclusions}

P. oceanica is a member of the Posidoniaceae family and the most important species of the Mediterranean angiosperms.

The idea behind this review was to highlight that until recently researchers have described the roles of this angiosperm linked to the sea environmental health, and only indirectly to the health of humans as recipients of good environmental conditions. Despite its ecological role, this overview of the bioactive properties of $P$. oceanica allows the scientific community to consider this plant as a promising resource for human health.

In recent studies, P. oceanica-rich in secondary metabolites-has shown some important roles such as antioxidant, anti-inflammatory, antidiabetic, anti-glycation properties, and the ability to suppress cancer cell migration. It has also been shown that $P$. oceanica can act as an activator of autophagy through interaction with specific signal transduction pathways.

A future challenge should include studying the bioavailability of P. oceanica secondary metabolites and thus the actual beneficial effects on human health to propose this angiosperm for potential pharmacological applications.

Author Contributions: Conceptualization, D.D. and A.M.D.B.; writing-original draft preparation, M.V., A.M.D.B., and D.D.; writing—review and editing, M.V., A.M.D.B., D.D., E.B., and C.P.; super- 
vision, D.D.; funding acquisition, C.P. and D.D. All authors have read and agreed to the published version of the manuscript.

Funding: This research was funded by the University of Florence, Fondi di Ateneo 2021 to D.D.I., and by CIBM 2021.

Institutional Review Board Statement: Not applicable.

Data Availability Statement: Not applicable.

Conflicts of Interest: The authors declare no conflict of interest.

\section{References}

1. The Angiosperm Phylogeny Group. An update of the angiosperm phylogeny group classification for the orders and families of flowering plants: APG III. Bot. J. Linn. Soc. 2009, 161, 105-121. [CrossRef]

2. den Hartog, C.; Kuo, J.J. Taxonomy and biogeography in seagrasses. In Seagrasses: Biology, Ecology and Conservation; Larkum, A.W.D., Orth, R.J., Duarte, C.M., Eds.; Springer: Dordrecht, The Netherlands, 2006; pp. 1-23.

3. Papenbrock, J. Highlights in seagrasses' phylogeny, physiology, and metabolism: What makes them special? ISRN Bot. 2012, 2012, 103892. [CrossRef]

4. Procaccini, G.; Buia, M.C.; Gambi, M.C.; Perez, M.; Pergent, G.; Pergent-Martini, C.; Romer, J. The seagrasses of western Mediterranean. In World Atlas of Seagrasses; Green, E.P., Short, F.T., Eds.; University of California Press: Berkeley, CA, USA, 2003; pp. $48-58$.

5. Gobert, S.; Cambridge, M.T.; Velimirov, B.; Pergent, G.; Lepoint, G.; Bouquegneau, J.M.; Walker, D.I. Biology of Posidonia. In Seagrasses: Biology, Ecology and Conservation; Larkum, A.W.D., Orth, R.J., Duarte, C.M., Eds.; Springer: Dordrecht, The Netherlands, 2006; pp. 387-408.

6. Vacchi, M.; De Falco, G.; Simeone, S.; Montefalcone, M.; Morri, C.; Ferrari, M.; Bianchi, C.N. Biogeomorphology of the Mediterranean Posidonia oceanica sea grass meadows. Earth Surf. Process. Landf. 2016, 42, 42-54. [CrossRef]

7. Boudouresque, C.F.; Bernard, G.; Bonhomme, P.; Charbonnel, E.; Diviacco, G.; Meinesz, A.; Pergent, G.; Pergent-Martini, C.; Ruitton, S.; Tunesi, L. Protection and Conservation of Posidonia Oceanica Meadows; RAMOGE and RAC/SPA Publishers: Tunis, Tunisia, 2012; pp. 1-202.

8. Pasqualini, V.; Pergent-Martini, C.; Clabaut, P.; Pergent, G. Mapping of Posidonia oceanica using aerial photographs and side scan sonar: Application off the island of Corsica (France). Estuar. Coast. Shelf Sci. 1998, 47, 359-367. [CrossRef]

9. Bonhomme, D.; Boudouresque, C.F.; Astruch, P.; Bonhomme, J.; Bonhomme, P.; Goujard, A.; Thibaut, T. Typology of the reef formations of the Mediterranan seagrass Posidonia oceanica, and the discovery of extensive reefs in the Gulf of Hyères (Pro-vence, Mediterranean). Sci. Rep. Port-Cros Natl. Park 2015, 29, 41-73.

10. Buia, M.C.; Gambi, M.C.; Zupo, V. Structure and functioning of Mediterranean seagrass ecosystems: An overview. Biol. Mar. Mediterr. 2000, 7, 167-190.

11. Lepoint, G.; Havelange, S.; Gobert, S.; Bouquegneau, J.M. Fauna vs. flora contribution to the leaf epiphytes biomass in a Po-sidonia oceanica seagrassbed (Revellata Bay, Corsica). Hydrobiologia 1999, 394, 63-67. [CrossRef]

12. Boudouresque, C.F. Marine biodiversity in the Mediterranean: Status of species, populations and communities. Trav. Sci. Parc Natl. Port-Cros 2004, 20, 97-146.

13. Pergent, G. La protection légale de la Posidonie en France: Un outil efficace. Nécessité de son extension a d'autres pays Méditerranéens. In Les Espèces Marines a Protéger en Méditerranée: Rencontres scientifiques de la Cote Bleue; Boudouresque, C.F., Avon, M., Gravez, V., Eds.; GIS Posidonie: Marseille, France, 1991; pp. 29-34.

14. European Commission. Directive 2008/56/EC of the European Parliament and of the Council of 17 June 2008 establishing a framework for community actions in the field of marine environmental policy (marine strategy framework directive). O. J. Eur. Communities 2008, 164, 19-40.

15. Cornara, L.; Pastorino, G.; Borghesi, B.; Salis, A.; Clericuzio, M.; Marchetti, C.; Damonte, G.; Burlando, B. Posidonia oceanica (L.) Delile ethanolic extract modulates cell activities with skin health applications. Mar. Drugs 2018, 16, 21. [CrossRef] [PubMed]

16. Leri, M.; Ramazzotti, M.; Vasarri, M.; Peri, S.; Barletta, E.; Pretti, C.; Degl'Innocenti, D. Bioactive compounds from Posidonia oceanica (L.) Delile impair malignant cell migration through autophagy modulation. Mar. Drugs 2018, 16, 137. [CrossRef] [PubMed]

17. Vasarri, M.; Leri, M.; Barletta, E.; Ramazzotti, M.; Marzocchini, R.; Degl'Innocenti, D. Anti-inflammatory properties of the marine plant Posidonia oceanica (L.) Delile. J. Ethnopharmacol. 2019, 247, 112252. [CrossRef]

18. Piazzini, V.; Vasarri, M.; Degl'Innocenti, D.; Guastini, A.; Barletta, E.; Salvatici, M.C.; Bergonzi, M.C. Comparison of chitosan nanoparticles and soluplus micelles to optimize the bioactivity of Posidonia oceanica extract on human neuroblastoma cell migration. Pharmaceutics 2019, 11, 655. [CrossRef]

19. Barletta, E.; Ramazzotti, M.; Fratianni, F.; Pessani, D.; Degl'Innocenti, D. Hydrophilic extract from Posidonia oceanica inhibits activity and expression of gelatinases and prevents HT1080 human fibrosarcoma cell line invasion. Cell Adhes. Migr. 2015, 9, 422-431. [CrossRef] [PubMed]

20. Vasarri, M.; Barletta, E.; Ramazzotti, M.; Degl'Innocenti, D. In vitro anti-glycation activity of the marine plant Posidonia oceanica (L.) Delile. J. Ethnopharmacol. 2020, 259, 112960. [CrossRef] 
21. Bay, D. A field study of the growth dynamics and productivity of Posidonia oceanica (L.) Delile in Calvi Bay, Corsica. Aquat. Bot. 1984, 20, 43-64. [CrossRef]

22. Micheli, C.; D’Esposito, D.; Belmonte, A.; Peirano, A.; Valiante, L.M.; Procaccini, G. Genetic diversity and structure in two protected Posidonia oceanica meadows. Mar. Environ. Res. 2015, 109, 124-131. [CrossRef]

23. Vassallo, P.; Paoli, C.; Rovere, A.; Montefalcone, M.; Morri, C.; Bianchi, C.N. The value of the seagrass Posidonia oceanica: A natural capital assessment. Mar. Pollut. Bull. 2013, 75, 157-167. [CrossRef]

24. Campagne, C.S.; Salles, J.-M.; Boissery, P.; Deter, J. The seagrass Posidonia oceanica: Ecosystem services identification and economic evaluation of goods and benefits. Mar. Pollut. Bull. 2015, 97, 391-400. [CrossRef]

25. Personnic, S.; Boudouresque, C.F.; Astruch, P.; Ballesteros, E.; Blouet, S.; Bellan-Santini, D.; Bonhomme, P.; Thibault-Botha, D.; Feunteun, E.; Harmelin-Vivien, M.; et al. An ecosystem-based approach to assess the status of a Mediterranean ecosystem, the Posidonia oceanica seagrass meadow. PLoS ONE 2014, 9, e98994. [CrossRef] [PubMed]

26. Bellisario, B.; Camisa, F.; Abbattista, C.; Cimmaruta, R. A network approach to identify bioregions in the distribution of Mediterranean amphipods associated with Posidonia oceanica meadows. Peer] 2019, 7, e6786. [CrossRef]

27. El Din, N.G.S.; El-Sherif, Z.M. Nutritional value of Cymodocea nodosa and Posidonia oceanica along the western Egyptian Mediterranean coast. Egypt. J. Aquat. Res. 2013, 39, 153-165. [CrossRef]

28. Bay, D. Etude in Situ de la Production Primaire d'un Herbier de Posidonies Posidonia oceanica (L.) Delile de la Baie de Cal-vi-Corse. Ph.D. Thesis, University of Liège, Liège, Belgium, 1978; p. 251.

29. Boudouresque, C.F.; Bernard, G.; Bonhomme, P.; Charbonnel, E.G.; Diviacco, E.; Meinesz, A.; Pergent, G.; Pergent-Martini, C.; Ruitton, S.; Tunesi, L. Préservation et Conservation des Herbiers à Posidonia Oceanica; RaMoGe Publishing: Monaco, 2006; pp. 1-202.

30. Dauby, P.; Bale, A.J.; Bloomer, N.; Canon, C.; Ling, R.D.; Norro, A.; Robertson, J.E.; Simon, A.; Théate, J.M.; Watson, A.J.; et al. Particle fluxes over a Mediterranean seagrass bed: A one-year sediment trap experiment. Mar. Ecol. Prog. Ser. 1995, 126, 233-246. [CrossRef]

31. Fonseca, M.S.; Koehl, M.; Kopp, B.S. Biomechanical factors contributing to self-organization in seagrass landscapes. J. Exp. Mar. Biol. Ecol. 2007, 340, 227-246. [CrossRef]

32. Mateo, M.; Lizaso, J.L.S.; Romero, J. Posidonia oceanica "banquettes": A preliminary assessment of the relevance for meadow carbon and nutrients budget. Estuar. Coast. Shelf Sci. 2003, 56, 85-90. [CrossRef]

33. Benoit, G.; Comeau, A. A sustainable future for the Mediterranean. In The Blue Plan's Environment and Development Outlook, 1st ed.; Benoit, G., Comeau, A., Eds.; Earth Scan: London, UK, 2005; p. 462.

34. Orth, R.; Carruthers, T.J.B.; Dennison, W.C.; Duarte, C.M.; Fourqurean, J.W., Jr.; Hughes, A.R.; Kendrick, G.; Kenworthy, W.J.; Olyarnik, S. A global crisis for seagrass ecosystems. BioScience 2006, 56, 987-996. [CrossRef]

35. Waycott, M.; Duarte, C.M.; Carruthers, T.J.B.; Orth, R.J.; Dennison, W.C.; Olyarnik, S.; Calladine, A.; Fourqurean, J.W.; Heck, K.L.; Hughes, A.R.; et al. Accelerating loss of seagrasses across the globe threatens coastal ecosystems. Proc. Natl. Acad. Sci. USA 2009, 106, 12377-12381. [CrossRef] [PubMed]

36. Bianchi, C.N.; Morri, C. Climate change and biological response in Mediterranean Sea ecosystems: A need for broad-scale and long-term research. Ocean. Chall. 2004, 13, 32-36.

37. Marbà, N.; Diaz-Almela, E.; Duarte, C.M. Mediterranean seagrass (Posidonia oceanica) loss between 1842 and 2009. Biol. Conserv. 2014, 176, 183-190. [CrossRef]

38. Gera, A.; Alcoverro, T.; Mascaró, O.; Pérez, M.; Romero, J. Exploring the utility of Posidonia oceanica chlorophyll fluorescence as an indicator of water quality within the European water framework directive. Environ. Monit. Assess. 2011, 184, 3675-3686. [CrossRef]

39. Pergent-Martini, C.; Leoni, V.; Pasqualini, V.; Ardizzone, G.; Balestri, E.; Bedini, R.; Belluscio, A.; Belsher, T.; Borg, J.; Boudouresque, C.; et al. Descriptors of Posidonia oceanica meadows: Use and application. Ecol. Indic. 2005, 5, 213-230. [CrossRef]

40. Carrasco-Acosta, M.; Garcia-Jimenez, P. Maintaining and storing encapsulated cells for propagation of Posidonia oceanica (L.) Delile. Aquat. Biol. 2021, 30, 47-57. [CrossRef]

41. De Lumley, H.; Pillard, B.; Pillard, F. L'habitat et les activités de l'homme du Lazaret. Une cabanne acheuléenne de la grotte du Lazaret (Nice). Mém. Soc. Préhist. Fr. 1969, 7, 183-222.

42. Weddell, H.A. Note sur les aegagropiles de mer. In Proceedings of the Actes du Congrès International de Botanique, Amsterdam, The Netherlands, 13-17 April 1877; pp. 58-62.

43. Tackolom, V.; Drar, M. Flora of Egypt: Angiospermae, part Monocotyledones: Liliaceae musaceae. Bull. Fac. Sci. 1954, $30,1-648$.

44. Boudouresque, C.F.; Meinesz, A. Découverte de l'herbier de Posidonie. Cah. Parc Natl. Port-Cros 1982, 4, 1-79.

45. Le Floch, E. Contribution à Une Étude Ethnobotanique de la Flore Tunisienne; Ministère de l'Education Nationale et de la Recherche Scientifique: Tunis, Tunisia, 1983; pp. 1-402.

46. De Saint-Pierre, M.E.G. Sur la germination et le mode de développement du Posidonia caulini. Bull. Société Bot. Fr. 1857, 4, 575-577. [CrossRef]

47. Braun-Blanquet, J.; Roussine, N.; Negre, R. Les Groupements Végétaux de la France Méditerranéenne; Macabet Frères Publishing: Vaison-la-Romaine, France, 1952; pp. 1-297.

48. A\&L Canada Laboratories. Compost Management Program-Compost Analysis for Available Nutrients and Soil Suitability Criteria and Evaluation. 2012. Available online: https://www.alcanada.com/pdf/technical/compost/Compost_Handbook.pdf (accessed on 19 July 2021). 
49. Sauvageau, C. Observations sur la structure des feuilles des plantes aquatiques (suite). J. Bot. Paris 1890, 4, 181-192.

50. Lami, R. L'utilisation des végétaux marins des côtes de France. Rev. Bot. Appl. Agric. Tropic. 1941, 21, 653-670. [CrossRef]

51. Karleskint, G.; Turner, R.; Small, J. Introduction to Marine Biology, 3rd ed.; Cengage Learning Customer and Sales Support: Belmont, CA, USA, 2009; p. 573.

52. Batanouny, K.H. Wild Medicinal Plants in Egypt; Academy of Scientific Research and Technology: Cairo, Egypt, 1999.

53. Cazzuola, F. Le Piante Utili e Nocive Agli Uomini e Agli Animali Che Crescono Spontanee e Coltivate in Italia con Brevi Cenni Sopra la Coltura, Sopra i Prodotti e Sugli Usi Che se ne Fanno; Loescher Editore: Torino, Italy, 1880; pp. 1-217.

54. El-Mokasabi, F.M. Floristic composition and traditional uses of plant species at Wadi Alkuf, Al-Jabal Al-Akhder, Libya. Am. Eur. J. Agric. Environ. Sci. 2014, 14, 685-697.

55. Gokce, G.; Haznedaroglu, M.Z. Evaluation of antidiabetic, antioxidant and vasoprotective effects of Posidonia oceanica extract. J. Ethnopharmacol. 2008, 115, 122-130. [CrossRef]

56. Agostini, S.; Desjobert, J.-M.; Pergent, G. Distribution of phenolic compounds in the seagrass Posidonia oceanica. Phytochemistry 1998, 48, 611-617. [CrossRef]

57. Costa, J.; Desjobert, J.; Pergent, G. Variations in the concentration of phenolic compounds in the seagrass Posidonia oceanica under conditions of competition. Phytochemistry 2004, 65, 3211-3220. [CrossRef]

58. Cuny, P.; Serve, L.; Jupin, H.; Boudouresque, C.-F. Water soluble phenolic compounds of the marine phanerogam Posidonia oceanica in a Mediterranean area colonised by the introduced chlorophyte Caulerpa taxifolia. Aquat. Bot. 1995, 52, 237-242. [CrossRef]

59. Haznedaroglu, M.Z.; Zeybek, U. HPLC determination of chicoric acid in leaves of Posidonia oceanica. Pharm. Biol. 2007, 45, 745-748. [CrossRef]

60. Cariello, L.; Zanetti, L. Distribution of chicoric acid during leaf development of Posidonia oceanica. Bot. Mar. 1979, 22, 359-360. [CrossRef]

61. Grignon-Dubois, M.; Rezzonico, B. Phenolic fingerprint of the seagrass Posidonia oceanica from four locations in the Mediterranean Sea: First evidence for the large predominance of chicoric acid. Bot. Mar. 2015, 58. [CrossRef]

62. Cannac, M.; Ferrat, L.; Pergent-Martini, C.; Pergent, G.; Pasqualini, V. Effects of fish farming on flavonoids in Posidonia oceanica. Sci. Total Environ. 2006, 370, 91-98. [CrossRef] [PubMed]

63. Heglmeier, A.; Zidorn, C. Secondary metabolites of Posidonia oceanica (Posidoniaceae). Biochem. Syst. Ecol. 2010, 38, 964-970. [CrossRef]

64. Viso, A.-C.; Pesando, D.; Bernard, P.; Marty, J.-C. Lipid components of the Mediterranean seagrass Posidonia oceanica. Phytochemistry 1993, 34, 381-387. [CrossRef]

65. Klap, V.; Hemminga, M.; Boon, J. Retention of lignin in seagrasses: Angiosperms that returned to the sea. Mar. Ecol. Prog. Ser. 2000, 194, 1-11. [CrossRef]

66. Hammami, S.; Ben Salem, A.; Ashour, M.L.; Cheriaa, J.; Graziano, G.; Mighri, Z.; Mohamed, L.A. A novel methylated sesquiterpene from seagrass Posidonia oceanica (L.) Delile. Nat. Prod. Res. 2013, 27, 1265-1270. [CrossRef]

67. Bernard, P.; Pesando, D. Antibacterial and antifungal activity of extracts from the rhizomes of the Mediterranean seagrass Posidonia oceanica (L.) Delile. Bot. Mar. 1989, 32. [CrossRef]

68. Berfad, M.A.; Alnour, T.M.S. Phytochemical analysis and antibacterial activity of the 5 different extracts from the seagrasses Posidonia oceanica. J. Med. Plant. Stud. 2014, 2, 15-18.

69. Farid, M.M.; Marzouk, M.M.; Hussein, S.R.; Elkhateeb, A.; Abdel-Hameed, E.S. Comparative study of Posidonia oceanica L.: LC/ESI/MS analysis, cytotoxic activity and chemosystematic significance. J. Mater. Environ. Sci. 2018, 9, 1676-1682. [CrossRef]

70. Lorenzo, J.M.; Munekata, P.E.; Gomez, B.; Barba, F.J.; Mora, L.; Perez-Santaescolastica, C.; Toldra, F. Bioactive peptides as natural antioxidants in foods-A review. Trends Food Sci. Technol. 2018, 79, 136-147. [CrossRef]

71. Baptista, R.C.; Horita, C.N.; Sant'Ana, A.S. Natural products with preservative properties for enhancing the microbiological safety and extending the shelf-life of seafood: A review. Food Res. Int. 2019, 127, 108762. [CrossRef]

72. Kourkoutas, Y.; Proestos, C. Food Preservation: Challenges and Efforts for the Future. Foods 2020, 9, 391. [CrossRef] [PubMed]

73. Piva, G.; Fracassetti, D.; Tirelli, A.; Mascheroni, E.; Musatti, A.; Inglese, P.; Piergiovanni, L.; Rollini, M. Evaluation of the an-tioxidant/antimicrobial performance of Posidonia oceanica in comparison with three commercial natural extracts and as a treatment on fresh-cut peaches (Prunus persica Batsch). Postharvest. Biol. Tec. 2017, 124, 54-61. [CrossRef]

74. Benito-González, I.; López-Rubio, A.; Martínez-Abad, A.; Ballester, A.-R.; Falcó, I.; González-Candelas, L.; Sánchez, G.; LozanoSánchez, J.; Borrás-Linares, I.; Segura-Carretero, A.; et al. In-depth characterization of bioactive extracts from Posidonia oceanica waste biomass. Mar. Drugs 2019, 17, 409. [CrossRef]

75. Catanesi, M.; Caioni, G.; Castelli, V.; Benedetti, E.; D'Angelo, M.; Cimini, A. Benefits under the sea: The role of marine compounds in neurodegenerative disorders. Mar. Drugs 2021, 19, 24. [CrossRef] [PubMed]

76. Sureda, A.; Box, A.; Terrados, J.; Deudero, S.; Pons, A. Antioxidant response of the seagrass Posidonia oceanica when epiphytized by the invasive macroalgae Lophocladia lallemandii. Mar. Environ. Res. 2008, 66, 359-363. [CrossRef] [PubMed]

77. Tutar, O.; Marín-Guirao, L.; Ruiz, J.; Procaccini, G. Antioxidant response to heat stress in seagrasses. A gene expression study. Mar. Environ. Res. 2017, 132, 94-102. [CrossRef] [PubMed]

78. Holmer, M.; Marbà, N.; Lamote, M.; Duarte, C.M. Deterioration of sediment quality in seagrass meadows (Posidonia oceanica) invaded by macroalgae (Caulerpa sp.). Chesap. Sci. 2009, 32, 456-466. [CrossRef] 
79. Forrester, S.J.; Kikuchi, D.S.; Hernandes, M.S.; Xu, Q.; Griendling, K.K. Reactive oxygen species in metabolic and inflammatory signaling. Circ. Res. 2018, 122, 877-902. [CrossRef]

80. Liu, T.; Zhang, L.; Joo, D.; Sun, S.-C. NF-kB signaling in inflammation. Signal. Transduct. Target. Ther. 2017, 2, 17023. [CrossRef] [PubMed]

81. Micheli, L.; Vasarri, M.; Barletta, E.; Lucarini, E.; Ghelardini, C.; Degl'Innocenti, D.; Mannelli, L.D.C. Efficacy of Posidonia oceanica extract against inflammatory pain: In vivo studies in mice. Mar. Drugs 2021, 19, 48. [CrossRef]

82. Khandia, R.; Dadar, M.; Munjal, A.; Dhama, K.; Karthik, K.; Tiwari, R.; Yatoo, M.I.; Iqbal, H.M.; Singh, K.P.; Joshi, S.K.; et al. A Comprehensive review of autophagy and its various roles in infectious, non-infectious, and lifestyle diseases: Current knowledge and prospects for disease prevention, novel drug design, and therapy. Cells 2019, 8, 674. [CrossRef]

83. Liu, W.; Li, Q.; Hu, J.; Wang, H.; Xu, F.; Bian, Q. Application of natural products derivatization method in the design of targeted anticancer agents from 2000 to 2018. Bioorg. Med. Chem. 2019, 27, 115150. [CrossRef]

84. Colone, M.; Calcabrini, A.; Stringaro, A. Drug delivery systems of natural products in oncology. Molecules 2020, 25 , 4560. [CrossRef]

85. Petrovska, B.B. Historical review of medicinal plants' usage. Pharmacogn. Rev. 2012, 6, 1-5. [CrossRef] 